\title{
The Assessment of Certain Minerals Content in Mixed Feeds in Relation to the Laying Hens' Exploitation System (Organic vs. Conventional)
}

\author{
Maria BOLOGA*, Ioan M. POP, Aida ALBU, Lucia I. NISTOR (COTFAS) \\ Faculty of Animal Husbandry, University of Agricultural Sciences and Veterinary Medicine, \\ 3 Mihail Sadoveanu Alley, 700490 Iaşi, Romania; \\ *Corresponding author, email: mary_shoa@yahoo.com
}

Bulletin UASVM Animal Science and Biotechnologies 71(2) / 2014,

Print ISSN 1843-5262; Electronic ISSN 1843-536X

DOI:10.15835/buasvmcn-asb:10370

\begin{abstract}
Feedstuffs grown in certain geographic areas may be marginal or deficient in specific elements. Thus, poultry diets usually require supplementation to ensure an adequate intake of trace minerals. The aim of this paper was the assessment of calcium (Ca), phosphorus (P), magnesium (Mg) and sodium ( $\mathrm{Na}$ ) content in the mixed feeds from two different production systems (organic and conventional). Were analyzed ten samples of mixed feed used for the feeding laying hens from Brown hybrid at the age of 27 weeks in two units in Romania. Sampling and the preparation of samples were performed in compliance with the rules of the standards in force in Romania and harmonized with EU legislation (ISO 6869:2002); the method for the determination used was spectrophotocolorimetry method (UVmini 1240 SHIMADZU) for P, and for $\mathrm{Ca}, \mathrm{Mg}$ and $\mathrm{Na}$ was assessed by atomic absorption spectrometry method. Analysis of mixed feed samples revealed statistically significant differences $(\mathrm{p} \leq 0.05)$ between the two systems (organic vs. conventional) for the P content $(0.25 \mathrm{vs} .0 .26 \%)$ and $\mathrm{Mg}$ content ( 0.26 vs. $0.28 \%$ ). Statistically insignificant differences ( $\mathrm{p} \geq 0.05$ ) between the two systems (organic vs. conventional) were found for the Ca content (2.93 vs. $2.97 \%$ ) and Na content (1.706 vs. $1.712 \%$ ).
\end{abstract}

Keywords: conventional vs. organic, minerals content, mixed feed

Introduction. Minerals are the inorganic part of feeds or tissues. Minerals are required for the formation of the skeleton, as components of various compounds with particular functions within the body, as cofactors of enzymes, and for the maintenance of osmotic balance within the body of the bird. Calcium and phosphorus are essential for the formation and maintenance of the skeleton. Sodium, potassium, magnesium and chloride function with phosphates and bicarbonate to maintain homeostasis of osmotic relationships and $\mathrm{pH}$ throughout the body. Most of the calcium in the diet of the growing bird is used for bone formation, whereas in the mature laying fowl most dietary calcium is used for eggshell formation (NRC, 1994).
Feedstuffs grown in certain geographic areas may be marginal or deficient in specific elements. Thus, poultry diets usually require supplementation to ensure an adequate intake of trace minerals (Blair, 2008).

Aims and objectives. The aim of this paper was the assessment of calcium (Ca), phosphorus $(\mathrm{P})$, magnesium $(\mathrm{Mg})$ and sodium $\mathrm{Na}$ content in the mixed feeds from two different production systems (organic and conventional).

Materials and methods. Were taken ten samples of mixed fodder from a conventional unit from Barlad County and from a organic unit from Cluj County, profiled on laying hens exploitation. Pre-mixtures have contained similar ingredients, except for the chemical synthesis and of animal origin, which are notallowed in organic production. 
Tab. 1. The average of certain minerals content in mixed feeds given at the peak of laying (age of life birds - 27 weeks), in relation to the exploitation system of laying hens

\begin{tabular}{|c|c|c|c|c|c|}
\hline \multirow{2}{*}{\multicolumn{2}{|c|}{ Specification }} & \multirow{2}{*}{$\begin{array}{l}\text { No. of } \\
\text { samples }\end{array}$} & \multicolumn{2}{|c|}{$\begin{array}{c}\text { Interpretation of differences } \\
\text { (ANOVA) }\end{array}$} & \multirow{2}{*}{$\begin{array}{l}\text { As recommended by guidelines } \\
(\% / \mathrm{kg})\end{array}$} \\
\hline & & & $\bar{X} \pm s \bar{x}$ & V\% & \\
\hline \multirow{2}{*}{$\begin{array}{c}\text { Ca } \\
\% / \mathrm{kg}\end{array}$} & Conv. & 5 & $2.97 \pm 0,04$ & 3.13 & $3.7-4^{*}$ \\
\hline & Eco. & 5 & $2.93 \pm 0,02$ & 1.79 & $4.5^{* *}$ \\
\hline \multirow{2}{*}{$\begin{array}{c}\mathbf{P} \\
\% / \mathrm{kg}\end{array}$} & Conv. & 5 & $0.26 \pm 0,01^{a}$ & 9.81 & $0.33^{*}$ \\
\hline & Eco. & 5 & $0.25 \pm 0,004^{\mathrm{d}}$ & 3.18 & $0.54^{* *}$ \\
\hline \multirow{2}{*}{$\begin{array}{c}\mathbf{M g} \\
\% / \mathrm{kg}\end{array}$} & Conv. & 5 & $0.28 \pm 0,004^{a}$ & 3.06 & 7* \\
\hline & Eco. & 5 & $0.26 \pm 0,01^{\mathrm{b}}$ & 5.53 & $10 * *$ \\
\hline \multirow{2}{*}{$\begin{array}{c}\mathbf{N a} \\
\% / \mathrm{kg}\end{array}$} & Conv. & 5 & $1.712 \pm 0,004$ & 0.52 & $0.19 *$ \\
\hline & Eco. & 5 & $1.706 \pm 0,002$ & 0.31 & $0.17^{* *}$ \\
\hline
\end{tabular}

* Source: Commercial management guide for ISA Brown, 2011; ${ }^{* *}$ Source: Commercial management guide for free-range Lohmann Brown, 2011; ANOVA: ${ }^{\text {ab }}=$ statistically significant differences $(\mathrm{p} \leq 0.05)$ between samples.

Were analyzed ten samples of mixed feed used for the feeding laying hens from Brown hybrid at the age of 27 weeks in two units in Romania. Total phosphorus concentration in animal feeding stuffs was determined by using spectrophotometric method. Absorbance measuring was made on UVmini-1240 SHIMADZU spectrophotometer at a wavelength of $430 \mathrm{~nm}$ compared with the reference solution. Calcium, magnesium and sodium concentration of the samples was determined using atomic absorption spectrometry method (EN ISO 6869:2002). Absorbance was measured at a flame atomic absorption spectrophotometer AA-6300 SHIMADZU at a wavelength of $422.7 \mathrm{~nm}$ (for Ca), $285.2 \mathrm{~nm}$ (for $\mathrm{Mg}$ ) and $589 \mathrm{~nm}$ (for $\mathrm{Na}$ ) compared to the control solution of lanthanum/ cesium. The results of analyses were processed statistically by calculating the position and variation estimators (arithmetic average $\bar{x}$, respective the variance $S^{2}$, standard deviation $s$,

standard deviation of average $s_{\bar{x}}$ and coefficient of variation $\mathrm{V} \%$ ) and the significance of differences was determined using ANOVA Test: single factor.

Results and discussion. Analysis of mixed feed samples revealed statistically significant differences $(p \leq 0.05)$ between the two systems (organic vs. conventional) for the $\mathrm{P}$ content $(0.25$ vs. $0.26 \%)$ and $\mathrm{Mg}$ content $(0.26$ vs. $0.28 \%)$. Statistically insignificant differences $(p \geq 0.05)$ between the two systems (organic vs. conventional) were found for the Ca content ( 2.93 vs. $2.97 \%$ ) and $\mathrm{Na}$ content (1.706 vs. $1.712 \%$ )
(Tab. 1). The average values set for minerals concentration in mixed feed analyzed ( $\mathrm{Ca}, \mathrm{P}, \mathrm{Mg}$ and $\mathrm{Na}$ ) were below the recommended values in commercial management guides for the hybrids use. For the mixed feed derived from the ecological system lower content of minerals analyzed may be explained due to the growing stage of the plant at the time of the harvest; lower growth rate in the organic production system can be due to ban use of $\mathrm{N}$ fertilizers and minerals.

Conclusion. The current results show that the rearing system can influence the composition of mixed feeds in certain minerals. This study contributes to the resolution of this debate since it reveals considerable differences in the corresponding element concentrations between the mixed feeds originating from the conventional and organic systems.

For the mixed feed derived from the ecological system lower content of minerals analyzed a possible explanation can be the source and level of supplemental minerals, availability of pasture throughout range area and free access to soil.

\section{REFERENCES}

1. Blair R (2008). Nutrition and feeding of organic poultry, Faculty of Land and Food Systems, The University of British Columbia, Vancouver, British Columbia, Canada.

2. SR EN ISO 6869 (2002). Animal feeding stuffs. Determination of the contents of calcium, copper, iron, magnesium, manganese, potassium, sodium and zinc -Method using atomic absorption spectrometry.

3. NRC (1994). Nutrient Requirements of Poultry. Ninth Revised Edition. 